\title{
THE AMBIVALENCE OF MODERNISM FROM THE WEIMAR REPUBLIC TO NATIONAL SOCIALISM AND RED VIENNA
}

\author{
SIEGFRIED MATTL
}

Ludwig Boltzmann Institute for History and Society, Vienna

Peter Jelavich: Berlin Alexanderplatz: Radio, Film, and the Death of Weimar Culture (Berkeley, Los Angeles and London: University of California Press, 2006)

Edward Timms: Karl Kraus, Apocalyptic Satirist: The Post-war Crisis and the Rise of the Swastika (New Haven and London: Yale University Press, 2005)

Focusing on the spectacular propaganda exhibitions "Degenerate Art" and "Degenerate Music," critical studies of Nazism's art policy long considered the regime's public attack on modernism and the turn to pseudo-classicism as decisive proof of Nazism's reactionary character. Studies such as Die Kunst im Dritten Reich (1974), which inspired broader research on the topic in the early 1970s, subscribed to a modern conception of aesthetics in which art expresses complex systems of ideas in progress. Artistic style, from this perspective, corresponded to political tendencies and reflected the traditional divide between conservatism and progressivism. But those boundaries have become blurred in the wake of more recent research, which has demonstrated the involvement of modernist artists in Nazi art (e.g. members of the Bauhaus involved in National Socialist architecture or avant-garde filmmakers such as Walter Ruttmann in National Socialist propaganda films) and, conversely, the continual performance of popular jazz music in the Third Reich (e.g. in radio programmes). ${ }^{1}$ Seen against such instances of modernist collaboration and its own occasional mimicry of modernism, National Socialism acquires a more ambivalent profile, characterized by the ongoing conflict between reactionary factions and those who favoured modernization for various reasons.

Jonathan Huener and Francis R. Nicosia, eds., The Arts in Nazi Germany: Continuity, Conformity, Change (New York and Oxford, 2006). 
The two books examined here, Peter Jelavich's Berlin Alexanderplatz: Radio, Film, and the Death of Weimar Culture and Edward Timms's Karl Kraus, Apocalyptic Satirist: The Post-war Crisis and the Rise of the Swastika, offer valuable contributions to a better understanding of the complex relations between Nazism and artistic modernism. Though different in subject and methodology, both authors turn our attention from art to cultural policy and to National Socialism's struggle for cultural hegemony. While Jelavich presents an impressive account of the destruction of cultural freedom through his investigation into the fate of Döblin's experimental novel (which was adapted as a radio play, banned after the National Socialist success in the election of September 1930 and transformed in a narrative film version one year later), Timms's intellectual biography of the Austrian writer and journalist Karl Kraus deals explicitly with the paradoxes of National Socialist reactionary modernism, reflected in such groundbreaking books as Kraus's Third Walpurgis Night in the early 1930s. ${ }^{2}$

It all probably began in Zurich at the Cabaret Voltaire in 1916, when the German writer in -exile Hugo Ball read his poem "Karawane." With its meaningless syllables_- "jolifanto bambla o falli bambla" — the poem signalled nothing so much as the collapse of personality and language in the shadow of warfare and war propaganda. Dada was born, a new philosophy of art interpreted by Richard Huelsenbeck as seizure of literature by the reality of modern lifeone simultaneous entanglement of noise, colours and oscillating states of consciousness. With dada, artistic avant-garde style came to be associated, in the eyes of the general public, with political aims. But what was thought of as "revolutionary art" in 1919 and 1920 came to serve, with the political stabilization of the mid-1920s, as a literary technique to stimulate masterpieces of Weimar culture such as Döblin's novel Berlin Alexanderplatz (1929). The novel depicts neither the city nor its main character as coherent subjects, but as material and psychic nodes where contested discourses and competing acoustic and visual signs intermingle and entwine. Franz Biberkopf, the novel's proletarian protagonist, can only escape from delirium when he accepts his dependency upon the "Other" (in psychoanalytic terms) in a critical and self-reflecting way. Taken as a commentary on politics, Berlin Alexanderplatz evokes the disintegration of the liberal public sphere both by chiliastic (nationalist) movements and modern mass media. As Jelavich puts it, Döblin was "disgusted" by "the reduction of political thought to simplistic sloganeering that cons gullible citizens" (32). The novel, inspired by Döblin's expertise as a trained psychologist, is constructed of depictions of perceptions reminiscent of physicians' protocols and fragments of public speech, including such diverse materials as advertisements, anti-Semitic

Kraus withheld printing of Third Walpurgis Nacht. The book was published for the first time only in 1952. 
stereotypes and discourses on sexuality. As Jelavich argues, Döblin, unlike Sergei Eisenstein, does not make use of montage as a means of popular enlightenment (by contrasting or connecting images to construct complex ideas), but as a critical tool of observation. In the end, the two proclamations that close the book-one calling for a mass rally in support of socialism, the other calling for war-suggest, by mingling both via typographical interventions, that slogans do not refer to negotiable targets, but rather tend, intrinsically, to block rational communication.

Berlin Alexanderplatz is undoubtedly one of the most outstanding examples of literary modernism, characterized by the end of narration and the merging of different layers of discourse and language games. ${ }^{3}$ But an aesthetic reading can miss the point when it fails to consider culture as an agent in power politics, and here precisely lies the strength of Jelavich's book. Reconstructing the fate of the radio play The Story of Franz Biberkopf and Piel Jutzi's film Berlin Alexanderplatz, the book investigates the question of how and to what ends Döblin's work could become the centre of National Socialist attacks on modernism. The National Socialists' gains in the elections of September 1930 were followed by a series of violent acts against movie theatres and radio stations. As a principal attraction in public space, the movies provided a fitting target for National Socialist tactics to conquer the street by terror. At the same time, Nazi propagandists accused filmmakers, theatre owners and cultural institutions of influencing the German public with anti-nationalist films on topics ranging from imperial warfare to abortion and sexual reform. National Socialist terrorism also influenced bourgeois efforts to control the mass media through governmental film-censorship and radio boards, which were directed against popular culture as well as social criticism. Examining a range of documents from the censorship boards, which offer astonishing insights into the artistic ignorance and arrogant partisanship of the boards, Jelavich offers a brilliant account of anti-modernist tendencies in Weimar cultural policy. In a tight-knit circle, film and radio producers, theatre owners and the entertainment industry itself anticipated censorship by adapting to ethical and formal standards articulated by the boards under pressure of National Socialist terrorism.

According to Jelavich, Döblin's radio play was to become the first victim of National Socialist cultural propaganda, when the political board of the Berlin radio station refused to air it in late 1930. (The lucky existence of an earlier recorded radio programme enables Jelavich to do an impressive close reading and to present an exemplary analysis of the new medium's impact

See e.g. Klaus R. Scherpe, "Nonstop nach Nowhere City? Wandlungen der Symbolisierung, Wahrnehmung und Semiotik der Stadt in der Literatur der Moderne," in idem, Die Unwirklichkeit der Städte. Großstadtdarstellungen zwischen Moderne und Postmoderne (Hamburg, 1988), 136-7. 
on literature.) Piel Jutzi's famous film, produced soon afterwards, betrayed the novel's particularity by streamlining it along conventionalized narrative patterns - another consequence, as Jelavich remarks, of the National Socialist approach towards cultural policy, as the film market tried to avoid confrontations caused by (politically and/or stylistically) controversial films.

The chapter on the radio play The Story of Franz Biberkopf offers not only a comprehensive historical account of German radio policy, but also a unique comment to broaden our understanding of the aesthetic impact of new media. (German) media anthropology, starting with Friedrich Kittler's seminal text Gramophone, Film, Typewriter, has offered powerful insights into the transformative power of communications technology concerning the production and cultural interpretation of subjectivity: as soon as reality could be stored by technical devices and verbal and physical gestures were transmitted by machines, literature, for example, changed its topics and materials to deal with the uncanny scenery of the disembodied language. But, surprisingly, most of the studies on media's impact on human self-conception (and suggestibility) avoided analysing the hyperreality produced by radio. For example, in his very instructive book on telemedial warfare, Stefan Kaufmann concentrates on the shift towards spatial mobilization and the creation of a new type of hybrid politico-military leadership made possible by the omnipresence of voices on air. ${ }^{4}$ Most studies on radio seek, like Kaufmann's, to describe how the media finally became tools of propaganda. Jelavich, however, presents a compelling analysis of radio's aesthetic impact. Literary techniques such as internal monologue on radio erased the protagonists' lack of coherence, and the differentiation of individual voices introduced an unintentional surplus of meaning. Authentic sound bites lost their quality as document and easily turned into stereotypes. In Jelavich's words,

Readers of a novel can intone the words as they see fit; their own fantasies—not just visual but also acoustic-add considerably to every written work. But when a text is actually spoken, the reciter introduces inflections and intonations that provide a specific interpretation and hence narrowing of the opus. (109-10)

Döblin's Story of Franz Biberkopf thus offers an appropriate and dense source with which to debate the shift in communication deployed by broadcasting, which was replacing literary techniques and (together with the cinema) transforming disputing publics into entertained audiences. (It was precisely the fear of engaging affective mass culture directly that served as the main argument for strict governmental regulation of the radio system.)

4 Stefan Kaufmann, Kommunikationstechnik und Kriegsführung 1815-1945. Stufen medialer Rüstung (Munich, 1996), 281). 
Given the context of his book, Jelavich could have delved further into the relations between aesthetic transformations and fracturing of the public sphere with the increasing dominance of cinema and radio in the cultural life of the late Weimar Republic. As he writes in his introduction, Döblin and other modernists did not conceive of popular culture as a sphere opposed to high culture, and there are good reasons to consider that "Weimar culture" was built on the inseparableness of traditional cultural topoi and dancing halls, the expressionist images of Fritz Lang and G. W. Pabst, chiromancy, fashion, jazz and queer culture. ${ }^{5}$ Film and radio produced imaginary structures to integrate these genres and idioms into a common state of exaltation. From a critical perspective, Peter Sloterdijk observed a common pattern in Weimar's public life - the staged authenticity imposed by the new media. From expressionism to the alluring legs of Marlene Dietrich in Der blaue Engel, from the bloody comedy of Hitler's coup in 1923 to Brecht's Dreigroschenoper, from the funeral ceremony for Foreign Minister Walter Rathenau, murdered by nationalists in 1922, to the "Reichstagsbrand" in 1933, Sloterdijk detects a very similar mode of theatrical performance. "Americanism", a more precise contemporary term for the advance of mass culture and technology in post-war Germany, became, in its coincidence with the trauma of the lost war, loaded with mythical topics. But it still is hard to decide whether modernists like Döblin saw the emerging mass culture as a remedy for, or as the mirror of, a fundamental and unsolvable crisis. While Sloterdijk in his general comment on Weimar's intellectual culture suggests the term "cynical rationality" for a highly reflexive thinking which had to face its own incapacity to generate change, Jelavich avoids critical judgements on avant-garde ambivalence and unfortunatly confines his analysis to the political threats that shaped the artistic destiny of Döblins Biberkopf.

If both the cancellation of Döblin's radio play and the aesthetic degradation in Jutzi's film signify the death of "Weimar culture," what, then, is the meaning of this term? According to Jelavich, Weimar culture should be understood as a complex of "formally innovative and socially critical" works. Undoubtedly, Döblin and Brecht (another point of reference in Jelavich's book) can be reclaimed for this definition. But for many other representatives of Weimar culture-including

5 As Jürgen Manthey mentions, Döblin's female characters are shaped by Dostoevsky's protagonist Sonja and her self-sacrifice in Crime and Punishment; see Jürgen Manthey, "Geschäfte der Innenstadt. Alfred Döblin: Modern. Ein Bild aus der Gegenwart," in Deutsches Literaturarchiv Marbach (ed.), Denkbilder und Schaustücke. Das Literaturmuseum der Moderne (Marbach, 2006), S.90; "Neue Sachlichkeit" and the artists' regress to traditional techniques would serve as one fine example, as well as (revolutionary) architect Bruno Taut's stress of the romantic symbol of the crystal.

$6 \quad$ Peter Sloterdijk, Kritik der zynischen Vernunft, Bd 2 (Frankfurt am Main), 705. 
painters from "new objectivity" such Otto Dix, expressionists such as Max Pechstein, and representatives of the Bauhaus such as Oskar Schlemmer or Walter Gropius - social criticism was neither an explicit aim nor an interpretation they would have appreciated. Dix, for example, once complained to an interviewer about the misinterpretation of his war paintings as "anti-militaristic," as he himself remembered the war as a sublime event; and Schlemmer, in letters to National Socialist officials in the mid-1930s, insisted that his art strove to regain a sense of classicism. As Peter Ulrich Hein writes in his seminal text on the avant-garde between cultural criticism and fascism, most of the German modernists where inspired by nationalistic paradigms of cultural theory and committed to the idea of a national "German" art. (This should not surprise at all, since even the French cubists assumed to have "Celtic" roots or ancestors.7) Concepts of modernist national (or, perhaps better, völkisch) art are to be found at least as far back as the founding of the "Deutscher Werkbund" in 1907 to create a unifying national style and to overthrow the cultural fragmentations of industrial modernity. For these artists, the "national" character of their work seemed evident, and at least in the period up to 1936, many German modernists did not protest against the cultural policy of National Socialism as such, but only the injustice imposed on them by the misunderstanding of their own national, racial or similar aims. We may have to take into account the economic motives behind such complaints. Nevertheless, as Peter Ulrich Hein observes, the artists' frustration at not being appreciated by the National Socialist regime discredits the story of the German avant-garde. ${ }^{8}$

In the last two decades studies on the institutional structures of German cultural policy after 1933 have argued that corporatist organization represented the core of "Nazi art," formed in rivalry with antithetic tendencies. As Pamela Potter puts it in a survey on recent literature, "What made art 'Nazi' was not a particular aesthetic concept but the participation of the artists in the regime and the interpretation of the art in the media."9 As Jelavich indicates in his analysis of Hitlerjunge Quax, a Nazi propaganda film that exploited modernist techniques to perform "racial" bonds of a National Socialist Volksgemeinschaft, Nazi cultural policy focused on the role of art to make visible the (imagined) fundaments of völkische integration. What (and who) fit into this programme or what was excluded from the public sphere did not depend on style, genre

See Mark Antliff, Inventing Bergson: Cultural Politics and the Parisian Avant-Garde (Princeton, 1993).

8 Peter Ulrich Hein, Die Brücke ins Geisterreich. Künstlerische Avantgarde zwischen Kulturkritik und Faschismus (Reinbek bei Hamburg, 1992), 249.

9 Pamela Potter, "The Arts in Nazi Germany: A Silent Debate," Contemporary European History $15 / 4$ (2006), 590. 
or artistic techniques, those categories stressed by modern art history. Rather Nazi cultural policy was concerned with reorganizing the "aesthetic regime of art"10 along the new spatial formation of the "Third Reich"—with modernist (or formally innovative) art set in place in dynamic spheres like the militarytechnical complex and consumer industry, controlled by the regime's general "Aesthetization of Politics" and corporate design. Using Berlin Alexanderplatz as a prism, Jelavich offers a profound and new understanding of the historical process that led to the cultural hegemony of National Socialism, and his book offers a deeper understanding of the artistic limits of technological mass media. The book suggests - although the author does not explicitly draw this conclusion-a rethinking of National Socialist cultural politics beyond traditional aesthetics and the paradoxes of Nazi modernism.

Karl Kraus, the unique Viennese moralist, satirist, editor of Die Fackel (1899-1936) and author of most of this magazine's articles, was probably the first fundamentally to criticize virtual alliances between modernism and totalitarianism. Since expressionist poets (such as Richard Dehmel) lent their voice to war propaganda in 1914, Kraus, a former supporter of expressionism, went beyond merely accusing the tendency to preprocess language of being a tool of dehumanization within modernism. The poetical rupture of expressionist syntax, in Kraus's view, opened the way to erasing the difference "between the literal [and] the symbolic" (Timms, 536) and provided sheer militaristic brutalism with cultural sublimity, as Kraus unmasked in his magnum opus Die letzten Tage der Menschheit-a voluminous montage of Austrian and German war atrocities overlaid with graphic newspaper reports, patriotic literature and dramatized sketches depicting delirious sequences of everyday life during the "Great War." In the early 1920 S Kraus discovered in National Socialist propagandist Joseph Goebbels a particular brand of expressionism, which led him to observe the "rise of the swastika" closely and continually point to the hybrid "modernist" character of National Socialism. While Döblin, when quoting National Socialist slogans in Berlin Alexanderplatz, centred on the topic of communication, modern mass media and the disintegration of personality, Kraus's more narrow focus was on the fate of language at a time when the boulevard press and party propaganda

10 The term "aesthetic regime of art" serves Jacques Rancière in replacing cultural theory notions like "modern" and "modernism," which have become debatable due to their teleological implications (as a marker of the constant progress of humanity). Rancière's concept stresses modern art's function of offering new ways of living (lebensformen) to be redistributed by the political system, but rejects a genuine and autonomous critical quality of formal innovation in the arts. Referring, e.g., to Flaubert's realistic novels, he demonstrates how the (politically) conservative writer's work was misconceived by his contemporaries as significant "democratic" enunciation. 
worked hand in hand to destroy the liberal utopias of the public sphere. His life's work consisted in collecting and re-editing linguistic atrocities he found in the newspapers and denouncing linguistic aberrations as central catalysts in the crisis of modern politics in Austria and Germany.

Edward Timms presents Karl Kraus, the public intellectual who at the peak of his career attracted a community of some three thousand to four thousand people (among them Elias Canetti) to his lectures and sold between thirty thousand and forty thousand copies of his magazine, in the context of Austrian interwar history. Crucial developments from the birth of the democratic republic in 1918 to fascist corporatism in 1934 are presented though the unique prism of Kraus's own artistic and intellectual commentaries. Kraus's political commitment-which had started with a battle against the "false memory" (Timms, 65) of the war as one of the bases of right-wing culture, had turned into a conflict with the corrupt press that emerged from the inflation process, and had culminated in his sensational attack on the Viennese police chief in 1927 after more than eighty people were killed in a police massacre ${ }^{11}$ - finally gave way to a reconciliation with authoritarian Austrian politics in the face of the rise of German National Socialism.

Until that moment, Kraus's profile remained ambivalent, whether he was praised as the untouchable advocate of modern artistic precision (and artists' ethics) or criticized as an illiberal anti-modernist. Now, Timms dissolves some of that ambivalence by presenting the author as suffering from the confused idea that "culture" — as in the Austrian case-was signified by racism and panGerman political movements. Other aspects, like the impact of anti-Semitic and anti-feminist concepts on Kraus's thinking, still remain unsolved, despite Timms's work.

Unlike in Germany, Italy or France, avant-gardism never found a stronghold in Austria. "Viennese modernism" was concerned with the cultural hybridity caused by modernization; apart from attempts to aestheticize private life in the Wiener Werkstätte, it was not concerned with the utopia of art as a means to change politics and society. Public culture, even in the 1920s, was dominated by the imperial tradition and the corpus of classic German literature. Efforts to incorporate contemporary music and theatre into representative national festivals failed as early as 1920. Key figures of modernism such as Fritz Lang, Arnold

11 In July 1927 , police attacked some fifty thousand people protesting against a judicial decision exculpating far-right-wing manslayers of murder. More than eighty protesters were shot dead. This episode is considered the "turning point" in the history of the first republic. On a poster published all over the city, Kraus, with a single sentence, requested chief of police (and twice chancellor) Johann Schober to resign. The poster has become an icon of Austrian contemporary history. 
Schönberg and Robert Musil all eventually left Vienna for Berlin. Modernism in Vienna represented less a tool to advance modernization or adapt to a changing environment than a forum for sceptical reflection. Such reflection in 1919 prompted several artists to found the transient "council of intellectual workers," to support projects of anti-bourgeois social reform, but soon gave way to detachment from party politics and (facing the bourgeois parties' illiberalism) vague sympathies for social democracy.

Within the context of heated political controversies, Karl Kraus, too, sympathized with social democracy. Internationally admired reforms in housing policy, education and social welfare, principle items of a social democratic political programme, ensured significant intellectual support for "Red Vienna" and an aversion towards conservative Catholic and pan-German camps which called for the return of pre-war paternalism. But Kraus, like Musil and others, never saw himself as a protagonist of progressive cultural-political programmes. On the contrary, they avoided partisanship and claimed the role of objective, distanced observers, who guaranteed the autonomy of rational thought in the face of modern political disruption. Therefore Musil tried to reconcile science and literature by means of intertextuality, while Kraus emphasized poetry as a resource to nullify impurities imposed on language by modern society and politics. Lyrics should be able to reinstall, or at least to remind listeners of, a prior, unaltered organic unity of word and meaning. As an author of Die Fackel as well as in his public recitations of Offenbach operettas that celebrated the power of rhythmic (or "musical") language, Kraus found it important to insert poems into the counterprose of his montage techniques.

Following Gershom Sholem, contemporary critics, inspired by Kraus's vast appropriation of theological vocabulary and metaphors, debated whether or not he believed in the divine character of language. Language critique, as most scholarship on "Viennese modernism" has stressed, stood at the centre of local intellectual debate, generating among other things the linguistic formalism of the "Wiener Kreis" as a remedy for effecting "rational" political and social reform. But the concepts of the "messianic" character of (poetic) language that Sholem stressed sustained the faith in immanent revolutionary fissures, or at least in the spiritual power of linguistic authenticity. Can the same be said of Kraus? Should a text like Die letzten Tage der Menschheit be understood as a progressive political commentary or as a restorative sermon? Walter Benjamin in his essay on Kraus did not offer clear-cut answers to such questions. Even for Benjamin, Kraus's personality and style have a highly ambivalent status, revealing the socially contingent and distorted character of modern discourses (e.g. of the legal system) while at the same time reinstalling primordial "truth" (e.g. of female sexuality, a topic close to his famous critique of courts) by referring to the "nature" of mankind. As Benjamin's essay suggests, language for Kraus has no ethical or 
political aim in itself, but serves rather as the superior court for controlling (and condemning) modern discourses and institutions_-with Kraus himself acting as superior judge. While debates remain unresolved, Timms's brilliant biography suggests a convincing pragmatic solution to the above question; it suggests that reflections on theological concepts of the creative power of language served to strengthen Kraus's own satiric authorship. When language had become a force of deconstruction - "Ink, Technology and Death," as Timms entitles one chapter of the book-and could no longer be used for rational and ethical aims, satirical wit should become the "counter-creative" force, destroying "the finite through the contrast with the eternal idea," "eternal ideas" being understood here not in a theological, but rather an ethical, sense (220). In Kraus's Third Walpurgis Night (written in 1933 but published only after the war), Shakespeare and Goethe became the witnesses of those eternal ideas, with characters from King Lear and Faust prefiguring National Socialist stormtroopers. Satirical wit of course seemed inadequate to the threat of war and extermination, which Kraus once more represented as the paradoxical combination of modernization and myth. But because of its avoidance of narrative structure and its heroic anti-Fascist messages - there is no teleological Weltgericht at the end, as in Die letzten Tage der Menschheit-Third Walpurgis Night should be read, Timms argues, as an initial text of post-holocaust writing.

Kraus's personality, however, remains ambivalent. His obsession with journalistic infidelity to language developed into a hostility for the democratic public sphere at large. Jacques Le Rider criticizes Kraus precisely for his cultivation of nostalgia for the predemocratic state of absolutistic censorship, an era in which public discourse was merely confined to aesthetic topics. ${ }^{12}$ In keeping with this critique, Kraus did not have much to say about radio, the movies and hyperreality, so essential for a writer like Döblin. Though advanced in all kinds of "lettristic" strategies, using different fonts to enforce the meaning of a text or, on special occasions, adopting the design of scholastical editions of the Holy Bible to emphasize his comments from cited texts (132 ff), he was not concerned with the impact of radio's and cinema's aesthetics on perception-as long as they were regulated by the state and not commercialized. Radio rather offered him new opportunities for his aesthetics of performance, practised in his epochal lectures on Jacques Offenbach and Johann Nestroy. ${ }^{13}$ Kraus deeply trusted in the power of retroactivity and how classical texts by the method of re-enactment could work as a critical comment on modern phenomena.

12 Jacques Le Rider, Das Ende der Illusion. Die Wiener Moderne und die Krisen der Identität (Vienna, 1990), 352.

13 Johann Nestroy (1801-62), performer of his own plays onstage, was the most important Austrian satirist. He used improvised stanzas to circumvent censorship and to mock state authority as well as petty bourgeois attitudes. 
"Cynical rationality" vanished after the National Socialists came to power in 1933, and gave way to a reactionary turn. After supporting Austrian social democrats for more than a decade in their struggle against anti-Semitic conservatives and pan-Germans, Kraus became a follower of the Austrian fascist regime that was established in 1934. When Edward Timms seems to defend Kraus's vote for the "smaller evil," one wishes that he would at least maintain a critical distance on the subject. More appropriately still, he might have taken issue with Klaus Amann's conclusion that Austrian writers failed to recognize that their ethical culture could only be saved by democratic political action. How can we possibly grasp Kraus's critical exposure of National Socialist slogans in light of his doxology for Austrian dictators who established a "Christian German corporate state" built on (at least in 1934-5) concepts similar to those deployed at the time by National Socialists?

Kraus's support of Austrian fascism brings us back to Benjamin's observation concerning the metapolitical character of Kraus's work. As Benjamin wrote, for Kraus, "orthography stands above judicature." (In German, this point is conveyed through the wordplay of the phrase "Denn über der Rechtsprechung steht die Rechtschreibung.") When we look back on the twentieth century and the experience of totalitarian systems, this dictum becomes ominous: it reminds $u s$ of the reality of the persecution and extermination of intellectuals and artists under National Socialism, starting with the book-burning of 1933 . Moreover, this formula points to the illusions shared by modernist movements, and challenges one to reflect on the ways in which art could reconcile the processes of disintegration caused by modern technology and social fragmentation with humanity. In Third Walpurgis Night, Kraus denounced this illusion by presenting the disturbing fusion of modernity and barbarism that underlies fascism. But should we not consider the performative character of this judgement, so convincingly in line even with social Darwinistic theories of the civilization process? As I already asked above, what if fascism understood cultural policies merely as tools to gain political hegemony by establishing codes of inclusion and exclusion? What if modernism, which is constituted by the "aesthetic regime of arts," failed to strengthen rational concepts that are used to mediate conflicts stemming from modernization? What if the generally accepted divide between modernism and barbarism was nothing more than the paradoxical result of National Socialist counterpropaganda itself? As Walter Grasskamp observes in his book on German cultural politics after 1945, National Socialism's attack on modern art led to a "postwar-misapprehension" according to which modernism was the ultimate signifier of democracy ${ }^{14}$ - a belief unknown in Italy, where

14 Walter Gross Kamp, Die unbewältigte Moderne. Kunst und Offentlichkeit (Munich, 1994), 5. 135 . 
futurism and fascism coincided. In a more informed reading of Benjamin's dictum, critical inquiry in the history of judicature can perhaps function as a model to reflect on those aporias of modernism.

The atrocities committed under National Socialism can be linked only in part to the image of a return of atavistic or "primitive" impulses. Most of the crimes that were perpetrated were given a legal framework, something that was inherently necessary to keep the complex administrative system running. It is for that reason that recent theories of fascism, under the influence of postmodernism, stress the importance of the modern legal tradition to explain the deep structure of totalitarian governance. In State of Emergency, Giorgio Agamben analyses how justice was suspended while law was still in force in the shape of decrees issued by governmental order. ${ }^{15}$ The "state of emergency", as Agamben demonstrates, has since then become the faith (or the paradigm) of modern politics by weakening parliamentary processes and strengthening governmental power. Benjamin, in his reference to the juridical mentor of National Socialism, Carl Schmitt, discovered similarities between the politics of the "state of emergency" and modernist art, which was based on the idea of total sovereignty of both the political leader and the avant-garde artist. For Benjamin, the only way to overcome the contingent dangers inherent in this type of sovereignty consisted in the development of modern mass culture. Though illusory in itself, this assumption at least unlocked the barriers of traditional aesthetic discourse and helped to suspend the ideology of a virtual mastery of modernization's inner contradictions by art. By quoting a series of political statements from the time when Berlin Alexanderplatz arrived at the movies, Jelavich makes obvious that Döblin decided on something different, namely on a return to the classical liberal concepts of the individual:

The transformation of the Biberkopf of 1929, who stands at the end of Döblin's novel cautiously assaying the political agitation around him, to the fully autonomous Franz at the end of Jutzi's 1931 film in many ways paralleled Döblin's own increasing focus on the individual as the key to collective renewal. (238)

This tension between a modernist mode of representation and an ethical individualism with deep roots in liberalism foreshadows the end of avantgarde artistic aspirations. In Kraus's Third Walpurgis Night the ambivalence has a different valence: it marks the limits of modernist metaphysics and its belief in the power of art to preserve und shape articulations of non-alienated humanity in bourgeois society. Kraus finally doubted whether language was the remedy for destructive tendencies in modern society. Language seemed to have become "the chimera that devours its own children by rendering them incapable of distinguishing the literal from the symbolic" (Timms, 536).

15 Giorgio Agamben, Ausnahmezustand (Frankfurt am Main, 2004), 41. 